\title{
Graphic correlation of Argentine Precordillera and North American Lower/Middle Ordovician sections
}

\author{
1 Department of Geological Sciences, The Ohio State University, Columbus, Ohio 43210, USA. E-mail: wsweet@columbus.rr.com \\ 2 CONICET - Museo de Paleontología, Universidad Nacional de Córdoba, C. C. 1598, 5000 Córdoba, Argentina. \\ E-mail: galbanes@com.uncor.edu
}

\begin{abstract}
Present work demonstrates that a level equivalent to the proposed Whiterockian basal GSSP can be located graphically in a composite section anchored by the Niquivil section of the Argentine Precordillera. The FAD of Cooperignathus aranda in the Niquivil composite section, a candidate for GSSP of the Lower/Middle Ordovician boundary, projects to a level very close to the FAD of Tripodus laevis in the Whiterockian reference section. The conodont-based framework reported here includes the potential for recognition of the proposed Whiterock Canyon-based GSSP, the Cooperignathus aranda-based GSSP, and, possibly, the Baltoniodus triangularisbased GSSP, recently proposed.
\end{abstract}

\section{Introduction}

In a study completed more than four years ago, but published only recently, Sweet, Ethington and Harris (2005) report on the assembly by graphic means of a conodont-based composite reference section for the Whiterockian Series. The compiled reference section has six components, including the well-known section in Whiterock Canyon, Monitor Range, Nevada, in which Ross and Ethington (1991) sited the basal stratotype of the lower Middle Ordovician Whiterockian Series at the base of the Orthidiella brachiopod Zone. In their report, Sweet, Ethington and Harris compile the Whiterockian composite reference section graphically with the Ibexian/Whiterockian composite that was assembled by Sweet and Tolbert (1997) and with a major composite assembled in several steps by Sweet $(1979,1984,1995 a, 1995 b)$ from range-data on Ordovician conodonts in sections at more than 80 localities in eastern and western United States. Thus, the resultant composite section spans the entire Ordovician and serves as a template for evaluation and high-resolution correlations in this important system. The pan-Ordovician composite section is shown by Sweet (2005), who also comments on its assembly.

Until recently, discussions of temporal correlations of Ordovician rocks have been conducted within a very traditional biostratigraphic framework composed of biozones of varying type and scope. Conodonts and graptolites have been important in establishing and recognizing these biozones. Conodonts have been especially useful because of their common occurrence in a variety of lithofacies, because of the ease of their extraction from samples of marine rock, and because of the widespread distribution in Paleozoic and Triassic seas of many species. Despite these factors, however, it has not yet been possible to extend worldwide any particular scheme of biostratigraphic zones. However, because the distribution of conodonts in many Ordovician sections has been reported in non-zonal context these range data are especially useful in a method of stratigraphic correlation commonly termed graphic correlation.
In the Whiterock Canyon section, the conodont Tripodus laevis (or T. combsi) also appears for the first time at (or very near) the base of the Orthidiella Zone; hence, in subsequent discussions of Ordovician conodont biostratigraphy the first occurrence of $T$. laevis has commonly been used to mark the base of the Whiterockian Series and thus, in North America at least, of the Middle Ordovician. Graphic correlation of lower Middle Ordovician rocks in central Nevada demonstrates, however, that Tripodus laevis occurs first at a level some $40 \mathrm{csu}$ (= composite-standard units) below its first appearance in the Whiterock Canyon section. Thus T. laevis cannot serve as a reliable regional marker of the Whiterockian base. Indeed, Sweet, Ethington and Harris (2005) concluded that they were "...unable to identify a single conodont species, in a credible developmental sequence, to serve as biological marker of [the basal Whiterockian] boundary."

Although unable to cite the first occurrence of any conodont species as regional marker of the Whiterockian stadial base, Sweet, Ethington and Harris (2005) were able to integrate the Whiterock Canyon section graphically into their Whiterockian reference section. Thus they could demonstrate that the GSSP is 599 csu above the base of the pan-Ordovician composite section detailed in their report. Unfortunately, that level can be identified only in sections that can be compared graphically with the Whiterockian reference section established in Sweet, Ethington and Harris's report.

The purpose of this brief report is to demonstrate that a level equivalent to the Whiterockian basal GSSP can also be located graphically, with some confidence, in a composite section anchored by the Niquivil section of the Argentine Precordillera. Furthermore, it can be shown graphically that the FAD of Cooperignathus aranda in the Niquivil composite section, a candidate for GSSP of the Lower/Middle Ordovician boundary, projects to a level very close to the FAD of Tripodus laevis in the Whiterockian reference section that was assembled graphically by Sweet, Ethington and Harris (2005). Finally, it is also shown that graphic-correlation procedures may also enable assembly of a high-resolution, non-biozonal, international chronostratigraphic framework within which to address and solve problems of Ordovician correlation.

\section{Procedures}

Using range data abstracted from the literature for the Niquivil, Peña Sombría, and Yanso sections (Albanesi et al., 1998, Albanesi et al., 2003, 2004) a Precordilleran composite section was compiled, with the Niquivil section serving as SRS (= standard reference section). This essentially straightforward procedure yielded the correlations shown in Figure 1. Range data used are given in Table 1.

Next, in Figure 2, the Niquivil-based Precordilleran composite section, given in Table 1, was plotted against the North American Midcontinent Composite section, also given in Table 1. Data for the 


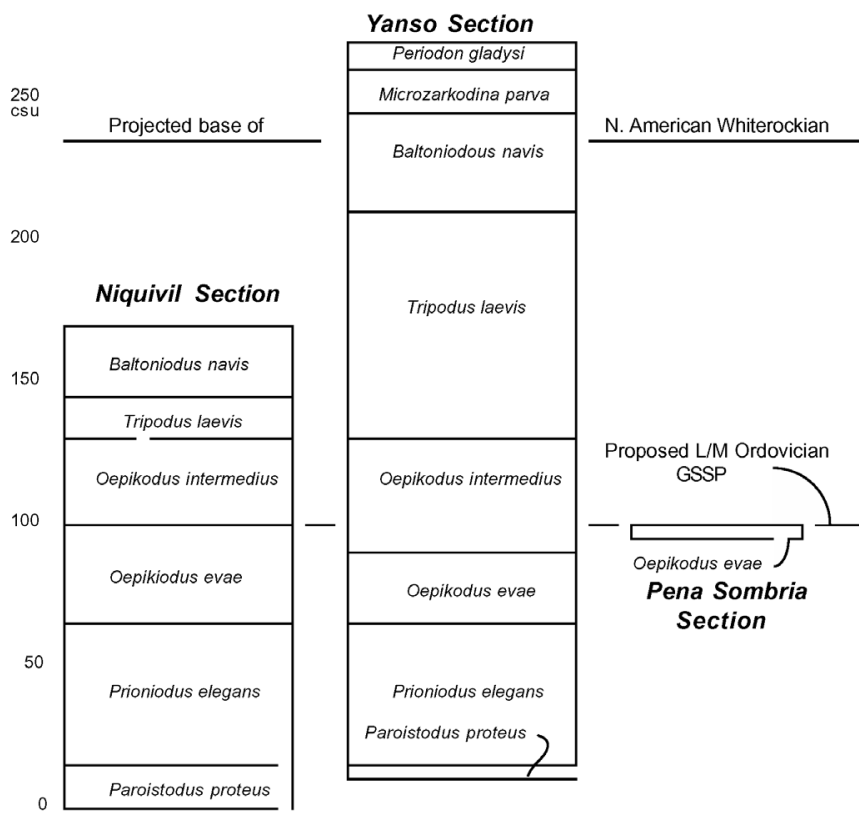

Figure 1 Relations between the three Precordilleran Ordovician sections compiled to form the Niquivil-based Composite Section. The Niquivil section is shown at its field-measured scale; the Yanso and Peña Sombría sections are shown at the vertical scale indicated by their graphic correlation with Niquivil. The Whiterockian base, which defines the L/M Ordovician boundary in North America, is projected at the level indicated in Figure 2.

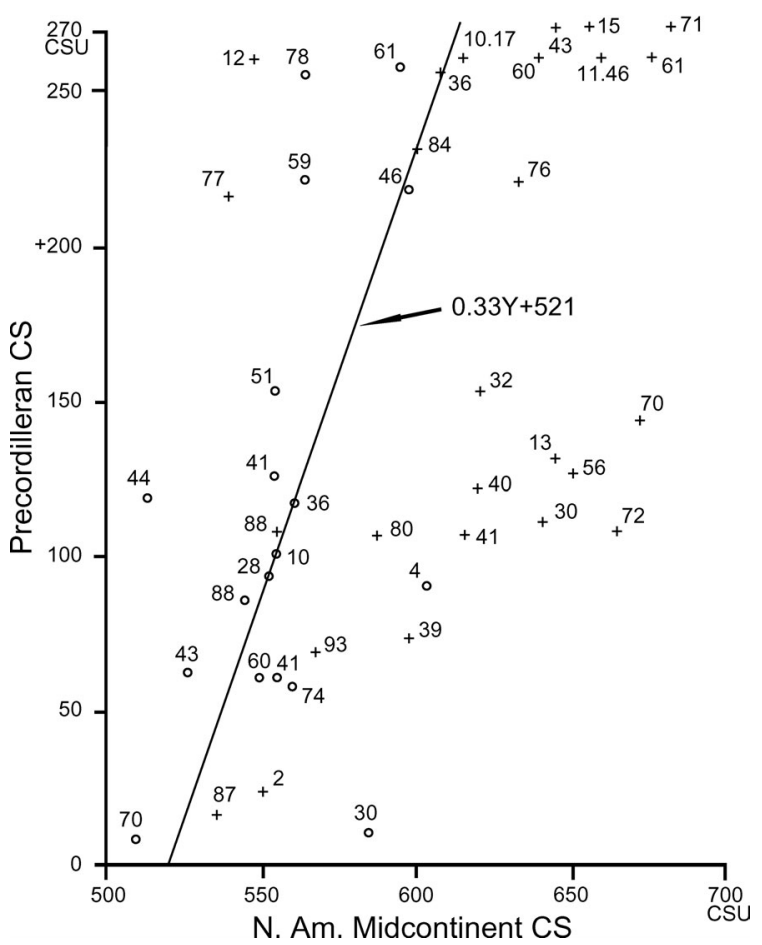

Figure 2 Graphic correlation of Niquivil-based Precordilleran CS and North American Midcontinent CS. Numerical data used in constructing graph are given in Table 1.

Table 1 Numbers given in columns headed Niq-B and Niq-T, PY-B and PY-T, and PS-B and PS-T are FADs and LADs of the conodont species named in the column headed "Species". In the columns headed .82PYB+7.4 and .82PYT+7.4, and .83PSB+94.13 and .83PST +94.13, FADs and LADs of species represented in the Yanso and Peña Sombría sections are listed in terms of the relations indicated by their graphic correlation with the Niquivil section. The columns headed CS-B and CS-T include the lowest and highest ranges of species given in columns to the left. The columns at the right, headed MCB and MCT list the FADs and LADs in the N. American Midcontinent Composite Standard section of the species listed in the column headed "Species."

\begin{tabular}{|c|c|c|c|c|c|c|c|c|c|c|c|c|c|c|c|}
\hline$\ldots$ & Species & Niq-B & $\mathrm{Niq}-\mathrm{T}$ & $P Y=B$ & $P Y=T$ & $P S-B$ & $P S-T$ & $82 \mathrm{PYB}+7$. & $4.82 \mathrm{PYT}+7.4$ & $83 P S B+94.13$ & $83 P S T+94.13$ & CS-B & CS-T & $\mathrm{MCB}$ & $\mathrm{MCT}$ \\
\hline 2 & Acodus deltatus & 21 & 22 & 0 & 2 & & & 7 & 9 & & & 7 & 22 & 340 & 550 \\
\hline 3 & Anodontus longus & 13 & 14 & & & & & & & & & 13 & 14 & & \\
\hline 4 & Ansella jemtlandica & 133 & 134 & 99 & 320 & 5 & 23.5 & 89 & 270 & 98 & 114 & 89 & 270 & 606 & 806 \\
\hline 6 & Baltoniodus navis & & & 248 & 279 & & & 211 & 236 & & & 211 & 236 & & \\
\hline 7 & B. norrlandicus & & & 309 & 309 & & & 261 & 261 & & & 261 & 261 & & \\
\hline 8 & B. triangularis & & & 277 & 277 & & & 235 & 235 & & & 235 & 235 & & \\
\hline $8 \mathrm{~A}$ & Baltoniodus sp. & & & & & 22 & 22.5 & & & 112 & 113 & 112 & 113 & & \\
\hline 9 & Bergstr extensus & 46 & 104 & 0 & 120 & 1 & 5 & 7 & 106 & 95 & 98 & 7 & 106 & & \\
\hline 10 & Cooperign aranda & 100 & 134 & 129 & 310 & 7 & 23.5 & 113 & 262 & 100 & 114 & 100 & 262 & 554 & 614 \\
\hline 11 & Cornuodus longibasis & 46 & 104 & 8 & 310 & 1 & 13 & 14 & 262 & 95 & 105 & 14 & 262 & 260 & 658 \\
\hline $11 \mathrm{~A}$ & Costiconus costatus & & & & & 7 & 23.5 & & & 100 & 114 & 100 & 114 & & \\
\hline 12 & Decori peselephantis & 71 & 72 & 1 & 310 & 3 & 23.5 & 8 & 262 & 96 & 114 & 8 & 262 & 437 & 549 \\
\hline 13 & Diaphorodus russoi & & & 1 & 147 & & & 8 & 128 & & & 8 & 128 & 365 & 646 \\
\hline 14 & Dipahorodus tovei & & & 34 & 34 & & & 35 & 35 & & & 35 & 35 & & \\
\hline 15 & Drepanodus arcuatus & 14 & 139 & 0 & 320 & 2 & 23.5 & 7 & 270 & 96 & 114 & 7 & 270 & 315 & 654 \\
\hline $15 \mathrm{~A}$ & D. reclinatus & & & & & 1 & 1.5 & & & 95 & 96 & 95 & 96 & & \\
\hline 17 & D. basiovalis & & & 267 & 310 & & & 226 & 262 & & & 226 & 262 & 269 & 615 \\
\hline 19 & D. costatus & 120 & 121 & & & & & & & & & 120 & 121 & & \\
\hline 20 & D. forceps & 14 & 127 & 120 & 320 & 3 & 23.5 & 106 & 270 & 96 & 114 & 14 & 270 & 293 & 688 \\
\hline 21 & D. pitjanti & & & 244 & 310 & & & 208 & 262 & & & 208 & 262 & & \\
\hline 24 & D. venustus & & & 256 & 267 & & & 217 & 226 & & & 217 & 226 & 860 & 1245 \\
\hline 25 & Erraticodon balticus & & & 303 & 320 & & & 256 & 270 & & & 256 & 270 & 704 & 858 \\
\hline 26 & Fahr marathonensis & & & & & 2 & 23.5 & & & 96 & 114 & 96 & 114 & 413 & 735 \\
\hline 28 & Juanogn jaanussoni & 111 & 149 & 105 & 310 & & & 94 & 262 & & & 94 & 262 & 552 & 731 \\
\hline 29 & J. sserratus & & & 310 & 310 & & & 262 & 262 & & & 262 & 262 & & \\
\hline 30 & J. variabilis & 64 & 107 & 64 & 127 & 1 & 3 & 60 & 112 & 95 & 96 & 60 & 112 & 438 & 637 \\
\hline 31 & Jumudontus brevis & 46 & 47 & & & & & & & & & 46 & 47 & & \\
\hline 32 & Jumudontus gananda & 71 & 145 & 180 & 180 & & & 155 & 155 & & & 71 & 155 & 487 & 618 \\
\hline 33 & Kalidontus corbatoi & 46 & 47 & & & 1 & 1.5 & & & 95 & 96 & 46 & 96 & & \\
\hline 35 & Lundodus gladiatus & 71 & .72 & 99 & 132 & 1. & 5 & 89 & 116 & 95 & 98 & 71 & 116 & 235 & 279 \\
\hline 36 & Microz. flabellum & & & 298 & 303 & 22 & 22.5 & 252 & 256 & 112 & 113 & 112 & 256 & 559 & 606 \\
\hline 37 & M. parva & & & 294 & 303 & & & 244 & 256 & & & 244 & 256 & & \\
\hline 38 & Oelandodus elongatus & 14 & 21 & & & & & & & & & 14 & 21 & & \\
\hline 39 & Oelandodus costatus & & & 8 & 87 & & & 14 & 79 & & & 14 & 79 & 585 & 595 \\
\hline 40 & Oepikodus communis & 87 & 121 & 46 & 110 & & & 45 & 98 & & & 45 & 121 & 438 & 618 \\
\hline
\end{tabular}


(Continued)

\begin{tabular}{|c|c|c|c|c|c|c|c|c|c|c|c|c|c|c|c|}
\hline 41 & Oepikodus evae & 64 & 102 & 75 & 120 & 1. & 5 & 69 & 106 & 95 & 98 & 64 & 106 & 558 & 612 \\
\hline 42 & Oepikodus intermedius & 97 & 139 & 99 & 152 & & & 89 & 132 & & & 89 & 139 & & \\
\hline $42 \mathrm{~A}$ & Oepikodus n. sp. & & & & & 22 & 22.5 & & & 112 & 113 & 112 & 113 & & \\
\hline 43 & Oistodus lanceolatus & 67 & 147 & 168 & 320 & 11 & 22 & 145 & 270 & 103 & 112 & 67 & 270 & 527 & 647 \\
\hline 44 & O. multicorrugatus & 121 & 145 & & & & & & & & & 121 & 145 & 507 & 816 \\
\hline 45 & Oistodus striolatus & & & 2 & 310 & & & 9 & 262 & & & 9 & 262 & & \\
\hline 46 & Paltodus jemtlandicus & & & 256 & 310 & & & 217 & 262 & & & 217 & 262 & 599 & 658 \\
\hline 47 & Paltodus subaequalis & 14 & 21 & 1 & 108 & & & 8 & 96 & & & 8 & 96 & 301 & 372 \\
\hline 49 & Paracordy gracilis & 21 & 22 & 0 & 75 & & & 7 & 64 & & & 7 & 64 & 293 & 444 \\
\hline 50 & Parapalt. simpliccimus & 100 & 101 & 29 & 310 & & & 31 & 262 & & & 31 & 262 & & \\
\hline 51 & Parapand paracornu & & & 180 & 310 & & & 155 & 262 & & & 155 & 262 & 552 & 624 \\
\hline 52 & P. striatus & 97 & 100 & & & & & & & & & 97 & 100 & 279 & 816 \\
\hline 53 & Paroist. cordylodi. & 21 & 22 & & & & & & & & & 21 & 22 & & \\
\hline 55 & P. originalis & 71 & 140 & 99 & 320 & 1 & 23.5 & 89 & 270 & 95 & 114 & 71 & 270 & 561 & 685 \\
\hline 56 & P. paralellus & 14 & 98 & 1 & 140 & & & 8 & 122 & & & 8 & 122 & 298 & 650 \\
\hline 57 & P. proteus & 14 & 46 & 0 & 12 & & & 7 & 17 & & & 7 & 46 & & \\
\hline 58 & $P \cdot n \cdot s p$. & 93 & 94 & 129 & 132 & & & 113 & 116 & & & 93 & 116 & & \\
\hline 59 & Periodon ac. zgierz. & & & 259 & 320 & & & 220 & 270 & & & 220 & 270 & $\mathrm{~Pa}=563$ & $\mathrm{~Pa}=914$ \\
\hline 60 & P. flabellum & 64 & 138 & 99 & 310 & 1 & 23.5 & 89 & 262 & 95 & 114 & 64 & 262 & 554 & 640 \\
\hline 61 & P. gladysi & & & 309 & 310 & & & 261 & 262 & & & 261 & 262 & 599 & 676 \\
\hline 62 & P. primus & 14 & 21 & & & 2 & 2.5 & & & 96 & 96 & 14 & 96 & & \\
\hline 63 & P. selenopsis & & & 1 & 132 & & & 8 & 116 & & & 8 & 116 & & \\
\hline 65 & Polonodus galerus & & & 309 & 310 & & & 261 & 262 & & & 261 & 262 & & \\
\hline 67 & Prioniodus adami & & & 87 & 92 & & & 79 & 83 & & & 79 & 83 & & \\
\hline 68 & Prioniodus elegans & 14 & 67 & 8 & 75 & & & 14 & 69 & & & 14 & 69 & & \\
\hline 69 & Prioniodus oepiki & & & 0 & 1 & & & 7 & 8 & & & 7 & 8 & & \\
\hline 70 & Protopand elongatus & 80 & 145 & 2 & 152 & 1 & 1.5 & 9 & 132 & 95 & 95 & 9 & 145 & 508 & 676 \\
\hline 71 & P. gradatus & 71 & 139 & 34 & 320 & 1 & 23.5 & 36 & 270 & 95 & 114 & 36 & 270 & 479 & 735 \\
\hline 72 & P. leonardii & 14 & 108 & 0 & 120 & & & 7 & 106 & & & 7 & 108 & 428 & 666 \\
\hline 73 & P. nogamii & 111 & 147 & & & 5 & 5.5 & & & 98 & 99 & 98 & 147 & & \\
\hline 74 & $P$. rectus & & & 64 & 320 & & & 60 & 270 & & & 60 & 270 & 559 & 724 \\
\hline 76 & Protoprion papiliosus & 93 & 121 & 129 & 259 & & & 113 & 220 & & & 93 & 220 & 565 & 631 \\
\hline 77 & P. simplicissimus & 22 & 108 & 256 & 256 & & & 217 & 217 & & & 22 & 217 & 356 & 539 \\
\hline 78 & Pteracont cryptodens & & & 244 & 320 & & & 208 & 270 & & & 208 & 270 & 566 & 750 \\
\hline 80 & Reutterodus andinus & 22 & 108 & 0 & 120 & 1 & 3 & 7 & 106 & 95 & 96 & 7 & 108 & 489 & 588 \\
\hline 81 & Rossodus barnesi & 22 & 121 & 1 & 310 & 7 & 23.5 & 8 & 262 & 100 & 114 & 8 & 262 & & \\
\hline 82 & Scolopodus krummi & 14 & 106 & 1 & 127 & & & 8 & 112 & & & 8 & 112 & & \\
\hline 83 & S. oldstockensis & 64 & 139 & 99 & 277 & & & 89 & 235 & & & 64 & 235 & & \\
\hline $83 \mathrm{~A}$ & Scolopodus striatus & & & & & 5 & 23.5 & & & 98 & 114 & 98 & 114 & & \\
\hline 84 & Scolopodus rex & & & 147 & 279 & & & 128 & 236 & & & 128 & 236 & 260 & 598 \\
\hline 85 & Semiacont portreril. & 119 & 146 & 129 & 310 & 22 & 22.5 & 113 & 262 & 112 & 113 & 112 & 262 & & \\
\hline 86 & Spinodus spinatus & & & 236 & 310 & & & 201 & 262 & & & 201 & 262 & 466 & 466 \\
\hline 87 & Stiptognathus borealis & & & 1 & 8 & & & 8 & 14 & & & 8 & 14 & 432 & 537 \\
\hline 88 & Stolodus stola & 97 & 108 & 92 & 99 & 1 & 1.5 & 83 & 89 & 95 & 96 & 83 & 108 & 543 & 552 \\
\hline 89 & Texania heligma & 100 & 133 & 127 & 152 & 22 & 22.5 & 112 & 132 & 112 & 113 & 100 & 133 & & \\
\hline 90 & Triangulodus brevi. & 144 & 145 & & & & & & & & & 144 & 145 & & \\
\hline 91 & Tripodus laevis s.l. & 128 & 150 & 147 & 277 & & & 128 & 235 & & & 128 & 235 & 554 & 730 \\
\hline $91 \mathrm{~A}$ & Tripodus sp. & & & & & & & & & 112 & 113 & 112 & 113 & & \\
\hline 92 & Tripodus australis & 80 & 107 & 99 & 129 & 22 & 22.5 & 89 & 113 & & & 80 & 113 & & \\
\hline 93 & Tropodus comptus & 14 & 73 & 2 & 46 & & & 9 & 45 & & & 9 & 73 & 347 & 571 \\
\hline 94 & Tripodus sweeti & 14 & 106 & 0 & 103 & 1. & 1.5 & 7 & 92 & 95 & 96 & 7 & 106 & & \\
\hline 95 & Ulrichodina quad. & 0 & 21 & & & & & & & & & 0 & 21 & & \\
\hline 96 & Walliserodus costatus & & & 267 & 310 & & & 226 & 262 & & & 226 & 262 & & \\
\hline
\end{tabular}

latter were extracted from the right-hand column of Appendix B in the report by Sweet, Ethington and Harris (2005). In Figure 2, note that a line of correlation (LOC), with the equation $0.33 \mathrm{Y}+521$, defines the boundary between an area of the graph that includes nearly all the FADs (plotted as circles) from an area that includes nearly all the LADs (plotted as crosses). Note, also, that a vertical line at MC-599 would intersect the LOC 235 csu above the base of the Niquivil-based composite section. That level, although well above the top of the Niquivil section itself, is the approximate equivalent in the Niquivil-based composite section of the basal Whiterockian GSSP. The Niquivil FAD of Cooperignathus aranda (species 10), proposed as marker of the Lower/Middle Ordovician boundary, projects to the 554 csu level in the North American Midcontinent composite section, some 45 csu below the projected base of the Whiterockian Stage. In short, formal sitting of the Lower/Middle Ordovician boundary GSSP at the FAD of Cooperignathus aranda in the Niquivil section of the Argentine Precordillera would substantially lower the position of that boundary in North American Ordovician sections - however, in the graphically-derived frame- work indicated in this report, one might easily recognize both the Whiterock Canyon-based GSSP and the Cooperignathus arandabased GSSP proposed in another part of this report.

Baltoniodus triangularis, whose FAD in the Huanghuachang section of China has been proposed as GSSP of the Lower/Middle Ordovician boundary (Stouge et al., 2005), is not known in the Ibexian-Whiterockian sections of western North American compiled by Sweet and Tolbert (1992) or Sweet, Ethington and Harris (2005), and it has been identified at only one level in the three components of the Precordilleran composite section compiled in this report. Thus, in at least the Argentine Precordillera and western North America, Baltoniodus triangularis would not be useful as a guide to the Lower/Middle Ordovician boundary. It is of interest to note, however, that the single level of occurrence of $B$. triangularis in Precordilleran sections, projects to the 599 csu-level in the IbexianWhiterockian composite section assembled graphically by Sweet, Ethington and Harris (2005). Thus, the conodont-based framework reported here includes the potential for recognition of the Whiterock Canyon-based GSSP proposed many years ago by Ross and Ething- 
ton (1991), the Cooperignathus aranda -based GSSP proposed by Albanesi et al. (2003, 2004), and, possibly, the Baltoniodus triangularis -based GSSP proposed recently by Stouge et al. (2005).

\section{Acknowledgements}

For continued support on Ordovician research, the authors thank CONICET (National Research Council of Argentina), the Universidad Nacional de Córdoba, Argentina, and The Ohio State University, Columbus, Ohio, USA.

\section{References}

Albanesi, G.L., Carrera, M.G., Cañas, F., and Saltzman, M., 2003, The Niquivil Section, Precordillera of San Juan, Argentina, Proposed GSSP for the Lower/Middle Ordovician boundary, in Albanesi, G.L., Beresi, M.S., and Peralta, S.H., (eds.), Ordovician from the Andes, Proceedings of the 9th International Symposium on the Ordovician System, San Juan, Argentina: Serie Correlación Geológica 17, INSUGEO, Tucumán, pp. $33-40$.

Albanesi, G.L., Carrera, M.G., Cañas, F.L., and Saltzman, M., 2004, Definition of a global boundary stratotype section and point (GSSP) for the base of the Middle Ordovician Series: The Niquivil section, Precordillera of San Juan, Argentina: Electronic report, International Subcommission on Ordovician Stratigraphy (ICS-IUGS), http://www.ordovician.cn, http://seis.natsci.csulb.edu/ordstrat 1 .

Albanesi, G.L., Hünicken, M.A., and Barnes, C.R., 1998, Bioestratigrafía de conodontes de las secuencias ordovícicas del cerro Potrerillo, Precordillera Central de San Juan, R. Argentina: Actas XII Academia Nacional de Ciencias, Córdoba, pp. 7-72.

Ross, R.J., Jr., Ethington, R.L., 1991, Stratotype of Ordovician Whiterock Series, with appendix on graptolite correlation of the topmost Ibexian by C.E. Mitchell: Palaios, 6, pp. 156-173.

Stouge, S., Wang, X., Li, Z, Chen, X., and Wang, C., 2005, The base of the Middle Ordovician series using graphic correlation method: Electronic report, International Subcommission on Ordovician Stratigraphy (ICSIUGS), http://www.ordovician.cn.

Sweet, W.C., 1979, Late Ordovician conodonts and biostratigraphy of the western Midcontinent Province: Brigham Young University Geology Studies, 26, 3, pp. 45-86.
Sweet, W.C., 1984, Graphic correlation of upper Middle and Upper Ordovician rocks, North American Midcontinent Province, U.S.A., in Bruton, D.L., (ed.), Aspects of the Ordovician System: Palaeontological Contributions from the University of Oslo, 295, pp. 23-35.

Sweet, W.C., 1995a, A conodont-based composite standard for the North American Ordovician: Progess report, in Cooper, J.D., Droser, M.L. and Finney, S.C., (eds.), Ordovician Odyssey, Short papers for the Seventh International Symposium on the Ordovician System: SEPM, Society for Sedimentary Geology, Pacific Coast Section, Fullerton, pp. 15-20.

Sweet, W.C. 1995b, Graphic assembly of a conodont-based composite standard for the Ordovician Sysem of North America, in Mann K.O. and Lane, H.R., (eds.), Graphic Correlation: SEPM, Society for Sedimentary Geology, Special Publication 53, pp. 139-150.

Sweet, W.C., 2005, Graphical refinement of the conodont database: examples and a plea: Special Papers in Palaeontology, 73, pp. 135-141.

Sweet, W.C., Ethington, R.L., and Harris, A.G, 2005, A conodont-based reference section in central Nevada for the lower Middle Ordovician Whiterockian Series: Bulletin American Paleontology, 369, pp. 33-50.

Sweet, W.C., Tolbert, C.M., 1997, An Ibexian (Lower Ordovician) reference section in the southern Egan Range, Nevada, for a conodont-based chronostratigraphy: United States Geological Survey Professional Paper, 1579-B, pp. 53-84.

Walter C. Sweet, Prof. Emeritus, Dept. Geological Sci., Ohio State University. Author or co-author of 4 books and more than 200 reports on conodonts, nautiloid cephalopods, and Ordovician and Permo-Trassic biostratigraphy, with emphasis on graphic correlation. B.S. Colorado College, 1950; M.S., Ph.D., 1952, 54, University of Iowa. Extensive field studies in central and western U. S., Bolivia, Norway, northern Italy. and China. Fellow, medallist, and past-president Paleontological Society.

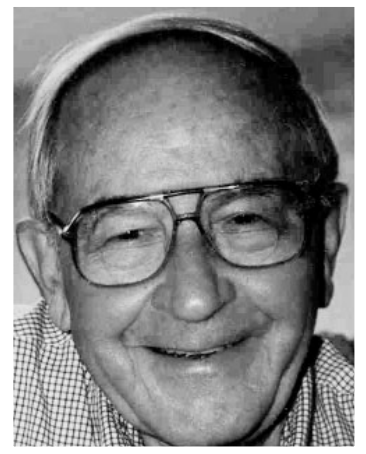

\section{The Neuquén Basin, Argentina}

\section{A Case Study in Sequence Stratigraphy and Basin Dynamics}

\section{Edited by}

\section{G.d. Veiga, L.A. Spallettti, J.A. Howell and E. Schwarz}

The Neuquén Basin of northern Patagonia provides an excellent case study in basin analysis and sequence stratigraphy. The basin is one of the largest petroleum provinces in South America and includes a dramatic record of relative sea-level changes as well as a unique and globally important palaeontological record. Understanding this region is also central to unravelling the history of the Andes. The latest developments in the study of the area have been combined in this volume to give an integrated series of case studies that document the structural, igneous, sedimentological and palaeontological history of the region from the Triassic to the Recent. This publication provides an introduction into this fascinating region as well as a resource that includes the most complete and up-to-date studies of the area.

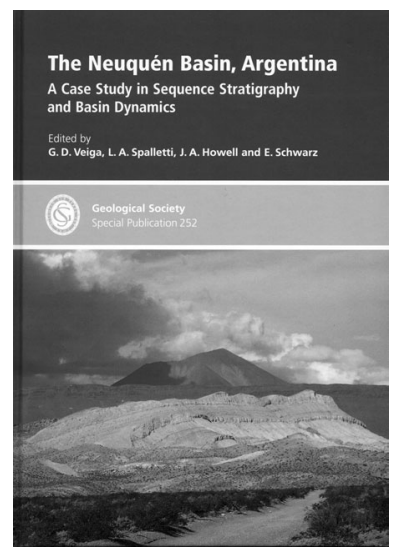

The Geological Society London, 2005

ISBN 1-86239-190-4

http://www.geolsoc.org.uk/bookshop http://www.geolsoc.org.uk 